\title{
Antitumor Properties of the Essential Oil From the Leaves of Duguetia gardneriana
}

Authors

Affiliations
Ana Carolina B. C. Rodrigues ${ }^{1}$, Larissa M. Bomfim ${ }^{1}$, Sara P. Neves ${ }^{1}$, Leociley R. A. Menezes ${ }^{2}$, Rosane B. Dias ${ }^{1}$, Milena B. P. Soares ${ }^{1,3}$, Ana Paula N. Prata ${ }^{4}$, Clarissa A. Gurgel Rocha ${ }^{1,5}$, Emmanoel V. Costa ${ }^{6}$, Daniel P. Bezerra ${ }^{1}$

The affiliations are listed at the end of the article

\author{
Key words \\ - Duguetia gardneriana \\ - Annonaceae \\ - essential oil \\ - cytotoxic \\ antitumor
}

\section{Abstract \\ $\nabla$}

Duguetia gardneriana, popularly known in the Brazilian northeast as "jaquinha", is a species belonging to the family Annonaceae. The aim of this work was to assess the chemical composition and antitumor properties of the essential oil from the leaves of $D$. gardneriana in experimental models. The chemical composition of the essential oil was analyzed via gas chromatography-flame ionization detector and gas chromatography-mass spectrometry. In vitro cytotoxic activity was determined in cultured tumor cells, and in vivo antitumor activity was assessed in B16-F10-bearing mice. The identified compounds were $\beta$-bisabolene $(80.99 \%)$, elemicin (8.04\%), germacrene D

\section{Introduction}

$\nabla$

Duguetia gardneriana Mart., popularly known as "jaquinha", is a species belonging to the family Annonaceae that has been found in the northeast Brazilian states of Sergipe, Pernambuco, and Paraiba [1]. Plants from the genus Duguetia have been used in folk medicine to treat several diseases. Moreover, some species have been reported to be a source of cytotoxic agents, such as Duguetia hadrantha R.E. Fr. [2], Duguetia glabriuscula R.E. Fr. [3], Duguetia odorata J.F. Macbr. [4], Duguetia furfuracea Saff. [5], and Duguetia lanceolata A.St.-Hil. [6].

There are currently only two available scientific research reports on $D$. gardneriana. In the first, Almeida et al. [7] described the isolation of three alkaloids (discretamine, tetrahydrojathrorrizine, and tetrahydropalmatine) and a cinnamate derivative (methyl 3,5-dihydroxy-4-ethoxycinnamate) from the ethanol extract of the stem bark. The second reported the chemical composition and antimicrobial activity of essential oil from the leaves obtained in the state of Paraiba, Brazil,
(4.15\%), and cyperene (2.82\%). The essential oil exhibited a cytotoxic effect, with $\mathrm{IC}_{50}$ values of $16.89,19.16,13.08$, and $19.33 \mu \mathrm{g} / \mathrm{mL}$ being obtained for B16-F10, HepG2, HL-60, and K562 cell lines, respectively. On the other hand, $\beta$-bisabolene was inactive in all of the tested tumor cell lines (showing $\mathrm{IC}_{50}$ values greater than $25 \mu \mathrm{g}$ / $\mathrm{mL}$ ). The in vivo analysis revealed tumor growth inhibition rates of $5.37-37.52 \%$ at doses of 40 and $80 \mathrm{mg} / \mathrm{kg} /$ day, respectively. Herein, the essential oil from the leaves of $D$. gardneriana presented $\beta$-bisabolene as the major constituent and showed cytotoxic and antitumor potential.

Supporting information available online at http://www.thieme-connect.de/products

which presented germacrene $\mathrm{D}$, viridiflorene, $\beta$ pinene, $\alpha$-pinene, and $\beta$-caryophyllene as the major constituents and showed antimicrobial activity against Staphylococcus aureus and Candida guilliermondii [8]. The aim of this work was to assess the chemical composition and antitumor properties of the essential oil from the leaves of D. gardneriana, obtained in the northeast Brazilian state of Sergipe, in experimental models.

\section{Results and Discussion \\ $\nabla$}

In relation to its dry weight, the leaves of $D$. gardneriana resulted in $0.13 \pm 0.04 \%$ essential oil (light yellow). As shown in $\bigcirc$ Table 1, four compounds were identified. The essential oil from the leaves of $D$. gardneriana is composed predominantly of sesquiterpene compounds. The identified compounds were $\beta$-bisabolene (80.99\%), elemicin (8.04\%), germacrene D (4.15\%), and cyperene (2.82\%). The presence of $\beta$-bisabolene in $D$. gardneriana as a major compound is reported here for the first time; however, this compound has 


\begin{tabular}{|llllr|}
\hline Compounds & & $\mathbf{R}^{\mathbf{a}}$ & $\mathbf{R}^{\mathbf{b}}$ & Leaves oil \% \\
\hline $\mathbf{1}$ & Cyperene & 1396 & 1398 & $2.82 \pm 0.46$ \\
\hline $\mathbf{2}$ & Germacrene D & 1479 & 1484 & $4.15 \pm 0.24$ \\
\hline $\mathbf{3}$ & $\beta$-Bisabolene & 1507 & 1505 & $80.99 \pm 0.35$ \\
\hline $\mathbf{4}$ & Elemicin & 1547 & 1555 & $8.04 \pm 0.01$ \\
\hline & Sesquiterpene identified & & & $96.00 \pm 0.45$ \\
\hline & Total identified & & $96.00 \pm 0.45$ \\
\hline
\end{tabular}

Table 1 Chemical composition of the essential oil from the leaves of D. gardneriana.

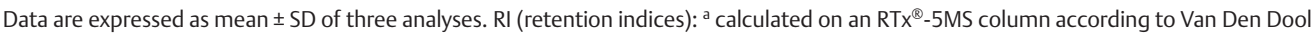
and Kratz [19], based on a homologous series of normal alkanes; ${ }^{b}$ according to ADAMS [20]

\begin{tabular}{|llll|}
\hline Cell lines & Essential oil & $\begin{array}{l}\mathbf{I C}_{\mathbf{5 0}}(\boldsymbol{\mu g} / \mathbf{m L})^{\mathbf{a}} \\
\boldsymbol{\beta} \text {-Bisabolene }\end{array}$ & $\mathbf{5 - F U}^{\mathbf{b}}$ \\
\hline Tumor cells ${ }^{\mathrm{c}}$ & 16.89 & $>25$ & 0.68 \\
\hline B16-F10 & $13.96-20.43$ & $>25$ & $0.21-1.45$ \\
\hline HepG2 & 19.16 & & 0.04 \\
\hline HL-60 & $16.06-22.85$ & $>25$ & $0.01-1.22$ \\
\hline K562 & 13.08 & $>25$ & 0.15 \\
\hline Non-tumor cells ${ }^{d}$ & $7.937-21.55$ & & $0.01-1.86$ \\
\hline PBMC & 19.33 & & 0.29 \\
& $11.06-33.80$ & $>25$ & $0.21-0.38$ \\
\hline
\end{tabular}

Table 2 In vitro cytotoxic evaluation of the essential oil from the leaves of $D$. gardneriana and of its major constituent, $\beta$-bisabolene.

a Data are presented as $\mathrm{IC}_{50}$ values, in $\mu \mathrm{g} / \mathrm{mL}$, and their $95 \%$ confidence interval obtained by nonlinear regression from three independent experiments performed in duplicate, measured by Alamar blue assay after $72 \mathrm{~h}$ incubation; ${ }^{\mathrm{b}}$ 5-Fluorouracil ( 5 -FU) was used as the positive control; ' Tumor cells: B16-F10 (mouse melanoma), HepG2 (human hepatocellular carcinoma), HL-60 (human promyelocytic leukemia), and K562 (human chronic myelocytic leukemia); ${ }^{\mathrm{d}}$ Non-tumor cell: PBMC (human peripheral blood mononuclear cells activated with concanavalin A - human lymphoblast)

been detected as a minor constituent in the essential oil of Uvaria pierrei Finet \& Gagnep. and Uvaria dac Pierre ex Finet \& Gagnep., two species belonging to the family Annonaceae [9]. The results presented in this work are very different from those of Almeida et al. [8]. In addition, other compounds are described for the first time in the genus Duguetia, such as elemicin and cyperene. These variations in the reported composition of the major constituents of $D$. gardneriana and in the contents of all of its components may be related to soil and climate conditions, water stress, the site of collection, nutrition, and other abiotic factors.

Since this major component presented a good separation and resolution by thin-layer chromatography (TLC), it was submitted to preparative TLC from the oil product and confirmed as $\beta$-bisabolene via MS and based on the subsequent NMR 1D and 2D spectra. TLC is an efficient, reproducible, and cheap technique, and, although $\beta$-bisabolene is a volatile compound, it was isolated in a sufficient amount for all tests. The ${ }^{1} \mathrm{H}$ and ${ }^{13} \mathrm{C}$ NMR data for this compound are presented in Supporting Information and are described for the first time here.

The chemical constituents of essential oils from plants belonging to the genus Duguetia include spathulenol and muurolol in the fine stems and germacrene D, cyperene, and muurolol in the stem bark of Duguetia flagellaris [10]. In the essential oil from the leaves of D. glabriuscula, the presence of aromadendrane sesquiterpenoids was observed [11]. On the other hand, in the essential oil from the bark of $D$. lanceolata, $\beta$-elemene, caryophyllene oxide, $\beta$-selinene, $\beta$-eudesmol, and humulene epoxide II were observed as major compounds [6].
The in vitro cytotoxic effects of the essential oil and its major constituent, $\beta$-bisabolene ( $\bullet$ Fig. 1 ), were assessed in four tumor cell lines using the Alamar blue assay after $72 \mathrm{~h}$ of incubation ( $\mathrm{Ta}$ ble 2). The essential oil exhibited a cytotoxic effect on all of the tested tumor cell lines, with half-maximal inhibitory concentration $\left(\mathrm{IC}_{50}\right.$ ) values of $16.89,19.16,13.08$, and $19.33 \mu \mathrm{g} / \mathrm{mL}$ being obtained in B16-F10, HepG2, HL-60, and K562 cells, respectively. $\beta$-Bisabolene was inactive in all of the tested tumor cell lines (showing $\mathrm{IC}_{50}$ values greater than $25 \mu \mathrm{g} / \mathrm{mL}$ ). In our preclinical anticancer drug screening program, extracts/oils presenting $\mathrm{IC}_{50}$ values below $30 \mu \mathrm{g} / \mathrm{mL}$ and pure compounds presenting IC $_{50}$ values below $4 \mu \mathrm{g} / \mathrm{mL}$ in the tumor cell line assays are considered promising [12-18]. Therefore, the essential oil obtained from $D$. gardneriana presented promising results, and these effects were associated with a mixture of its constituents. For 5-fluorouracil (5-FU), which was used as the positive control, $\mathrm{IC}_{50}$ values of 0.04 to $0.68 \mu \mathrm{g} / \mathrm{mL}$ were observed in the HepG 2 and B16-F10 cell lines, respectively.

The cytotoxicity of the essential oil was also evaluated against non-tumor cells (PBMCs). The selectivity index (SI) was determined as $\mathrm{IC}_{50}[\mathrm{PBMC}] / \mathrm{IC}_{50}[\mathrm{HL}-60]$. The essential oil showed an $\mathrm{SI}$ of 3.6, while 5-FU showed an SI of 93.3.

In the genus Duguetia, the alkaloids hadranthine B, imbiline-1, and sampangine from the stem bark of $D$. hadrantha have been shown to induce cytotoxic effects in different tumor cell lines [2]. Matos et al. [3] reported the cytotoxic effects of seven constituents isolated from $D$. glabriuscula in Hep2 human larynx carcinoma cells, in which $\beta$-sitosterol exhibited an $\mathrm{IC}_{50}$ value below $5 \mu \mathrm{g} / \mathrm{mL}$. Oliveroline isolated from $D$. odorata inhibits the $G_{2}$ 
DNA damage checkpoint in MCF-7 mp53 cells [4]. Duguetine and duguetine $\beta$-N-oxide isolated from the subterranean stem bark of $D$. furfuracea present potent cytotoxic effects in different tumor cell lines [5]. Moreover, the essential oil from the bark of $D$. lanceolata shows a cytotoxic effect in brine shrimp [6]. Additionally, we have been continually investigating the antitumor potencial of essencial oils from species belonging to the family Annonaceae. Among these, some essential oils from plants from the genera Xylopia and Guatteria have been shown to exhibit significant in vitro and in vivo anticancer activity, without substancial systemic toxicity [12,14-17]. In this context, the in vitro cytotoxic effect, as well as, in vivo antitumor activity of the essential oil from the leaves of $D$. gardneriana were assessed for the first time in this study.

In vivo antitumor activity was evaluated using C57BL/6 mice subcutaneously inoculated with B16-F10 melanoma cells and treated once a day for nine consecutive days with the essential oil via the intraperitoneal route ( $\bullet$ Fig. 2 ). On the 16th day, the average tumor weight in the control mice was $3.87 \pm 0.20 \mathrm{~g}$. In the presence of the essential oil, administered at 40 and $80 \mathrm{mg} / \mathrm{kg} / \mathrm{day}$, the average tumor weights were $3.66 \pm 0.38$ and $2.42 \pm 0.39 \mathrm{~g}$, respectively. The observed tumor growth inhibition rates were $5.37-37.52 \%$. The administration of $5-\mathrm{FU}$ ( $25 \mathrm{mg} / \mathrm{kg} /$ day), as the positive control, reduced tumor weight by $43.11 \%$. In addition, tumor sections removed from all groups were subjected to histopathological analyses and showed intense pleomorphism, lumpy chromatin, abundant intracellular melanin pigment, and atypical mitoses.

Microscopic and macroscopic analyses of the organs and analyses of biochemical and hematological parameters were performed in the essential oil-treated mice to evaluate systemic toxicity. No significant changes in body or organ (liver, kidney, spleen, lung, and heart) weight were observed in the essential oil-treated groups ( $p>0.05$, Table $2 S$, Supporting Information). Microscopic analyses of the liver and kidneys revealed hydropic degeneration and vascular congestion in all groups. Atelectasis, focal hemorrhage, and vascular congestion were observed in the lungs of animals treated with the essential oil and 5-FU. In the spleen, moderate hyperplasia of the white pulp was observed in the essential oil-treated mice. All of these acutely injured cells returned to a homeostatic state when the stimulus ended. Microscopic analyses of the heart did not reveal alterations in any group. Moreover, no significant changes in peripheral blood biochemistry (alkaline phosphatase, gamma-glutamyl transpeptidase, alanine aminotransferase, albumin, globulin, total protein, blood urea nitrogen, creatinine, uric acid, phosphorus, calcium, amylase, cholesterol, and glucose) or hematological (total erythrocytes and leukocytes, and the proportions of neutrophils, lymphocytes, monocytes, eosinophils, and basophils) parameters were observed in the essential oil-treated groups ( $p>0.05$, Tables 35 and 4 S, Supporting Information).

In conclusion, the essential oil from the leaves of $D$. gardneriana presents $\beta$-bisabolene as the major constituent and shows cytotoxic and antitumor potential.

\section{Materials and Methods \\ $\nabla$ \\ Cells}

The tumor cells lines B16-F10 (mouse melanoma), HepG2 (human hepatocellular carcinoma), K562 (human chronic myelocytic leukemia), and HL-60 (human promyelocytic leukemia) were do- nated by the A. C. Camargo Hospital, São Paulo, SP, Brazil. The cells were maintained in Roswell Park Memorial Institute-1640 (RPMI-1640, Gibco-BRL) medium supplemented with 10\% fetal bovine serum (Cultilab), 2 mM L-glutamine (Vetec Química Fina), and $50 \mu \mathrm{g} / \mathrm{mL}$ gentamycin (Novafarma). Adherent cells were harvested via treatment with a $0.25 \%$ trypsin EDTA solution (GibcoBRL). All cell lines were cultured in cell culture flasks at $37^{\circ} \mathrm{C}$ in $5 \% \mathrm{CO}_{2}$ and subcultured every three to four days to maintain exponential growth. All experiments were conducted with cells in the exponential growth phase. All cell lines were tested for mycoplasma using the Lookout ${ }^{\circledR}$ Mycoplasma qPCR detection kit (Sigma-Aldrich), and all cells were shown to be free from contamination.

Heparinized blood (from healthy, 20- to 35-year-old, nonsmoking donors who had not taken any drugs for at least 15 days prior to sampling) was collected, and peripheral blood mononuclear cells (PBMCs) were isolated via a standard protocol using a Ficoll density gradient in GE Ficoll-Paque Plus. The PBMCs were washed and resuspended at a concentration of $0.3 \times 10^{6}$ cells $/ \mathrm{mL}$ in RPMI 1640 medium supplemented with $20 \%$ fetal bovine serum, $2 \mathrm{mM}$ glutamine, and $50 \mu \mathrm{g} / \mathrm{mL}$ gentamycin at $37^{\circ} \mathrm{C}$ with $5 \% \mathrm{CO}_{2}$. Concanavalin A (ConA; Sigma Chemical Co.) was used as a mitogen to trigger cell division in T-lymphocytes. ConA $(10 \mu \mathrm{g} /$ $\mathrm{mL}$ ) was added at the beginning of culture, and the cells were treated with the test drugs after $24 \mathrm{~h}$. The Research Ethics Committee of the Oswaldo Cruz Foundation (Salvador, Bahia, Brazil) approved the experimental protocol (number 031 019/2013). All participants signed a written informed consent form to participate in the study.

Cell viability was examined using the Trypan blue exclusion assay for all experiments. Over $90 \%$ of the cells were viable at the beginning of culture.

\section{Animals}

A total of 36 specific pathogen-free C57BL/6 mice (males, 25$30 \mathrm{~g}$ ) were obtained and maintained at the animal facilities of the Gonçalo Moniz Research Center-FIOCRUZ (Salvador, Bahia, Brazil). Animals were housed in cages with free access to food and water. All animals were kept under a 12:12-h light-dark cycle (lights on at 6:00 a.m.). The animals were treated according to the ethical principles for animal experimentation of the SBCAL (Brazilian Association of Laboratory Animal Science), Brazil. The Animal Ethics Committee of the Oswaldo Cruz Foundation (Salvador, Bahia, Brazil) approved the experimental protocol (number 01/2013).

\section{General experimental procedures}

MS spectra were acquired on a Shimadzu QP2010 GC/MS system equipped with an AOC-20i auto-injector, and 1D and 2D NMR data were recorded at $303 \mathrm{~K}$ in $\mathrm{CDCl}_{3}$ on a Bruker AVANCE III 600 NMR spectrometer operating at 14.1 Tesla, observing ${ }^{1} \mathrm{H}$ and ${ }^{13} \mathrm{C}$ at 600 and $150 \mathrm{MHz}$, respectively. All of the observed ${ }^{1} \mathrm{H}$ and ${ }^{13} \mathrm{C}$ NMR chemical shifts $(\delta)$ are presented in ppm in relation to the TMS signal at $0.00 \mathrm{ppm}$ as an internal reference and the coupling constant $(J)$ in $\mathrm{Hz}$. For analytical $(0.25 \mathrm{~mm})$ and preparative $(1.00 \mathrm{~mm}) \mathrm{TLC}$, silica gel $60 \mathrm{~F}_{254}$ was used. Compounds were visualized via exposure under $U_{254 / 365}$ light and spraying the p-anisaldeyde reagent, followed by heating on a hot plate. 


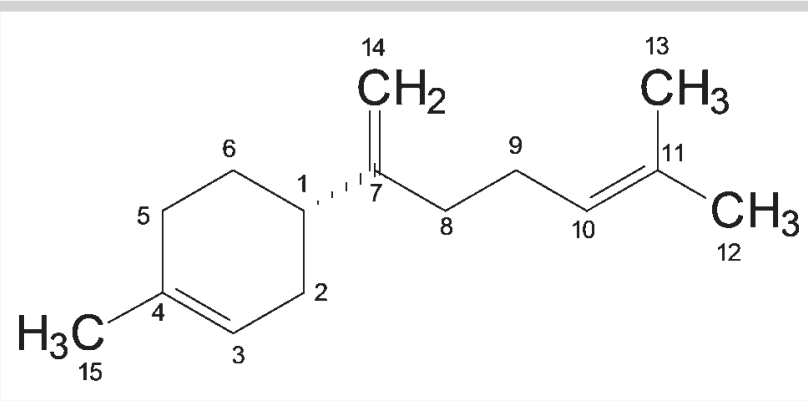

Fig. 1 Chemical structure of $\beta$-bisabolene.

\section{Botanical material}

Leaves of $D$. gardneriana were collected in November 2013, in the Itabaiana Mountain National Park, between the cities of Itabaiana and Areia Branca, Sergipe State, Brazil (coordinates: S $10^{\circ} 45^{\prime}$ $17.1^{\prime \prime}$ and $\left.\mathrm{W} 37^{\circ} 20^{\prime} 32.6^{\prime \prime}\right)$. The identity of the plant was confirmed by Dr. Ana Paula do Nascimento Prata of the Department of Biology of Federal University of Sergipe (UFS), Brazil, and a voucher specimen (32822) was deposited in the Herbarium of UFS (ASE/UFS). The authors have authorization from the Chico Mendes Institute for Biodiversity Conservation from the Brazilian Ministry of the Environment for plant collection (number 25637-1). This work was performed according to special authorization for access to genetic resources in Brazil \# 010344/2014-4, issued by $\mathrm{CNPq} / \mathrm{MCTI}$.

\section{Hydrodistillation of the essential oil}

Essential oil from the dried leaves (for $24 \mathrm{~h}$ ) of $D$. gardneriana $(200 \mathrm{~g})$ was obtained via hydrodistillation for $3 \mathrm{~h}$ using a Clevenger-type apparatus. The essential oil was dried over anhydrous sodium sulfate, and the percentage content was calculated on the basis of the dry weight of plant material. The oil was then stored in a freezer until analysis. Hydrodistillation was performed in duplicate.

\section{Gas chromatography-flame ionization detector and gas chromatography-mass spectrometry analysis} GC-FID and GC-MS analyses were performed on a Shimadzu GC2010 Plus GCMS-QP2010 Ultra GC-FID equipped with a Shimadzu AOC-20i auto-injector. Separation of the compounds was achieved in an $\mathrm{RTx}^{\circledR}$-5MS fused capillary chromatography column (30 m $\times 0.25 \mathrm{~mm} \times 0.25 \mu \mathrm{m}$ film thickness) coated with $5 \%$ diphenyl-95\%-dimethylpolysiloxane. Helium was used as the carrier gas at a flow rate of $1.2 \mathrm{~mL} / \mathrm{min}$. The column temperature program was $40^{\circ} \mathrm{C} / 4 \mathrm{~min}$, followed by an increase at a rate of $4{ }^{\circ} \mathrm{C} /$ min to $240^{\circ} \mathrm{C}$, then an increase at $10^{\circ} \mathrm{C} / \mathrm{min}$ to $280^{\circ} \mathrm{C}$ and holding $280^{\circ} \mathrm{C} / 2 \mathrm{~min}$. The injector and detector temperatures were $250^{\circ} \mathrm{C}$ and $280^{\circ} \mathrm{C}$, respectively. The injection volume of the essential oil in dichloromethane $(10.0 \mathrm{mg} / \mathrm{mL})$ was $1.0 \mu \mathrm{L}$, with a split ratio of $1: 50$. Retention indices were generated using a standard solution of $n$-alkanes $\left(C_{8}-C_{18}\right)$. Peak areas and retention times were measured with an electronic integrator. The relative amounts of individual compounds were computed from the obtained GC peak areas without an FID response factor correction. MS were collected at $70 \mathrm{eV}$, with a scan interval of $0.5 \mathrm{~s}$ and fragments of 40-550 Da. The components of the essential oil were identified by comparing the retention times of the GC peaks with standard compounds run under identical conditions and by comparison of

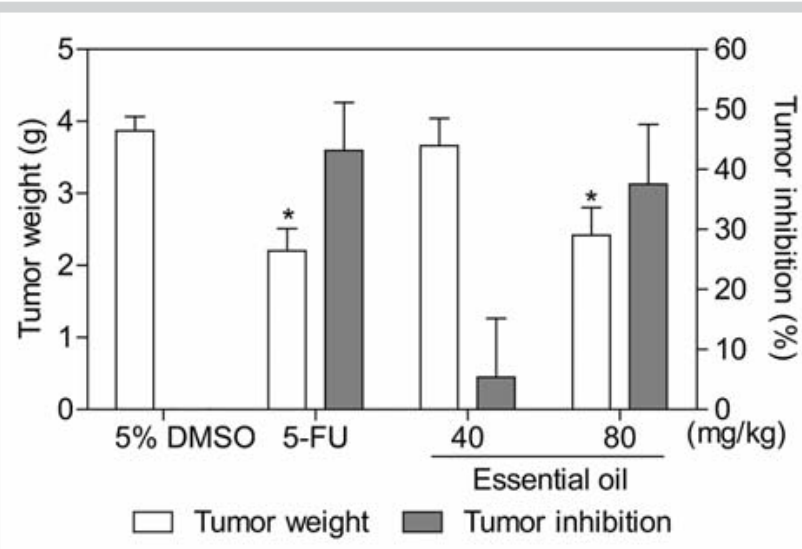

Fig. 2 In vivo antitumor effect of the essential oil from the leaves of D. gardneriana. Mice were injected with B16-F10 mouse melanoma cells $(2.0 \times 106$ cells/animal, s. c.). The animals were then treated via intraperitoneal administration for nine consecutive days, starting one day after tumor implantation. As the positive control, 5-fluorouracil (5-FU, $25 \mathrm{mg} / \mathrm{kg}$ ) was used. The negative control was treated with the vehicle used for diluting the tested substance ( $5 \%$ DMSO). Data are presented as the mean \pm SEM from nine animals per group. ${ }^{*} \mathrm{P}<0.05$ compared with the $5 \% \mathrm{DMSO}$ group via ANOVA followed by the Student-Newman-Keuls test.

the obtained retention indices [19] and MS [20] with those available in the literature in addition to comparison of the MS with those stored in the NIST and Wiley libraries. The analyses of the essential oil were performed in duplicate.

\section{$\beta$-Bisabolene isolation}

A portion of the essential oil $(200.0 \mathrm{mg})$ was also subjected to preparative TLC, eluted with a mixture of $n$-hexane-ethyl acetate (95:05, v/v), producing $136.5 \mathrm{mg}$ of the $\beta$-bisabolene compound (GC-FID, 95.0\%).

$\beta$-bisabolene: Colorless oil. $[\alpha]_{\mathrm{D}}^{25}-64.2$ (c $\left.0.7 \mathrm{~g} / 100 \mathrm{~mL}, \mathrm{CHCl}_{3}\right) ;{ }^{1} \mathrm{H}$ and ${ }^{13} \mathrm{C}$ NMR data, see Supporting Information; MS (EI, $\left.70 \mathrm{eV}\right): \mathrm{m} /$ $z(\%)=204\left(\mathrm{M}^{\cdot+}, 4\right), 161(8), 121(9), 119(18), 109(18), 107$ (19), 94 (24), 93 (57), 92 (13), 91 (26), 81 (10), 79 (34), 77 (21), 69 (100), 68 (15), 67 (47), 65 (10), 55 (21), 53 (21), 43 (10), 41 (90).

\section{In vitro cytotoxic activity assay}

Cell growth was quantified using the alamar blue assay as previously described [21]. Cells were seeded into 96-well plates for all experiments $\left(0.7 \times 10^{5}\right.$ cells $/ \mathrm{mL}$ for adherent cells or $0.3 \times 10^{6}$ cells/mL for cells suspended in $100 \mu \mathrm{L}$ of medium). After $24 \mathrm{~h}$, the essential oil $(0.39-50.0 \mu \mathrm{g} / \mathrm{mL})$ and its major constituent, $\beta$ bisabolene $(0.19-25.0 \mu \mathrm{g} / \mathrm{mL})$, dissolved in dimethyl sulfoxide (DMSO, Sigma-Aldrich), were added to each well and incubated for $72 \mathrm{~h}$. As a positive control, 5-FU (purity $>99 \%$; Sigma-Aldrich) was used. The negative controls received the vehicle employed for diluting the tested compound (0.5\% DMSO). Four hours (for cell lines) or 24 hours (for PBMCs) before the end of incubation, $20 \mu \mathrm{L}$ of a stock solution $(0.312 \mathrm{mg} / \mathrm{mL}$ ) of alamar blue (resazurin, Sigma-Aldrich Co.) was added to each well. Absorbance was measured using a SpectraMax 190 multiplate reader, and the drug effect was quantified as the percentage of the control absorbance at $570 \mathrm{~nm}$ and $600 \mathrm{~nm}$. The absorbance of alamar blue in the culture medium was measured at higher and lower wavelengths. The absorbance of the medium was also measured at higher and lower wavelengths. The absorbance of the medium alone was sub- 
tracted from the absorbance of the medium plus alamar blue at the higher wavelength. This value was referred to as $\mathrm{AO}_{\mathrm{HW}}$. The absorbance of the medium alone was subtracted from the absorbance of the medium plus alamar blue at the lower wavelength. This value was referred to as $\mathrm{AO}_{\mathrm{LW}}$. A correction factor, $R_{0}$, was calculated from $\mathrm{AO}_{\mathrm{HW}}$ and $\mathrm{AO}_{\mathrm{LW}}$, where $R_{0}=\mathrm{AO}_{\mathrm{LW}} / \mathrm{AO}_{\mathrm{HW}}$. The percent of reduction in alamar blue was expressed as follows: \% reduced $=A_{\mathrm{LW}}-\left(A_{\mathrm{HW}} \times R_{0}\right) \times 100$.

\section{In vivo antitumor activity assay}

The in vivo antitumor effect was evaluated in C57BL/6 mice inoculated with B16-F10 melanoma cells as previously described [18]. Tumor cells $\left(2 \times 10^{6}\right.$ cells per $\left.500 \mu \mathrm{L}\right)$ were implanted subcutaneously into the left hind groin of the mice. The essential oil was dissolved in 5\% DMSO and given to the mice intraperitoneally once a day for nine consecutive days. Mice were divided into four groups at the beginning of the experiment: Group 1 (negative control, $\mathrm{n}=9$ ): animals treated via injection of the vehicle (5\% DMSO); Group 2 (positive control, $n=9$ ): animals treated via injection of 5-FU ( $25 \mathrm{mg} / \mathrm{kg}$ ); Group 3: animals treated via injection of the essential oil ( $40 \mathrm{mg} / \mathrm{kg}, \mathrm{n}=9$ ); and Group 4: animals treated via injection of the essential oil $(80 \mathrm{mg} / \mathrm{kg}, \mathrm{n}=9)$. The treatments were initiated one day after tumor injection. On day 16, peripheral blood samples from the mice were collected from the retro-orbital plexus under phenobarbital (Aventis Pharma Ltda) for biochemical and hematological analyses, as described below. The animals were euthanized through cervical dislocation, and the tumors were excised and weighed. Drug effects are expressed as the percent of inhibition in relation to the control.

\section{Systemic toxicological evaluation}

Systemic toxicological effects were investigated as previously described [18]. The mice were weighed at the beginning and end of the experiment. The animals were observed for signs of abnormalities throughout the study. Their livers, kidneys, spleens, lungs, and hearts were removed, weighed, and examined for any signs of gross lesions or color changes and hemorrhage. Biochemical analyses of serum samples were performed using a Vet-16 rotor and quantified using an Analyst bench-top clinical chemistry system (Hemagen Diagnostics, Inc.). Hematological analyses were performed using light microscopy. Following a gross macroscopic examination, representative tissue sections of the tumors, livers, kidneys, spleens, lungs, and hearts were fixed in $4 \%$ formalin buffer and embedded in paraffin. Tissue sections with a thickness of $4 \mu \mathrm{m}$ were stained with hematoxylin and eosin, and a pathologist performed analyses under light microscopy.

\section{Statistical analysis}

Data are presented as means $\pm \mathrm{SEM} / \mathrm{SD}$ or $\mathrm{IC}_{50}$ values and their 95\% confidence intervals (CI 95\%), obtained via nonlinear regression. Differences between experimental groups were compared using ANOVA (analysis of variance) followed by the StudentNewman-Keuls test $(p<0.05)$. All statistical analyses were performed using the GraphPad program (Intuitive Software for Science).

\section{Supporting information}

Spectrometric data, including $1 \mathrm{D}\left({ }^{1} \mathrm{H}\right.$ and $\left.{ }^{13} \mathrm{C}\right)$ and 2D (COSY, HSQC and HMBC) NMR, GC-MS, GC-FID, and MS data, and systemic toxicological parameters (body and organ weight, periph- eral blood biochemistry, and hematologic parameters) are available as Supporting Information.

\section{Acknowledgements}

This work was financially supported by the Brazilian agencies CNPq, CAPES, FAPESB and FAPITEC/SE. The authors are grateful to Professor Dr. Andersson Barison for 1D and 2D NMR spectra and to Marlene da Silva Cerqueira for technical assistance and the histotechnology platform of FIOCRUZ-Bahia for performing histological techniques. The English was edited by American Journal Experts (key\# 6F4C-C714-BC72-8A16-991B).

\section{Conflict of Interest}

$\nabla$

The authors have declared that there is no conflict of interest.

\section{Affiliations}

${ }^{1}$ Gonçalo Moniz Research Center, Oswaldo Cruz Foundation (Fiocruz), Salvador, Bahia, Brazil

${ }^{2}$ Department of Chemistry, Federal University of Sergipe, São Cristóvão, Sergipe, Brazil

${ }^{3}$ Center of Biotechnology and Cell Therapy, Hospital São Rafael, Salvador, Bahia, Brazil

${ }^{4}$ Department of Biology, Federal University of Sergipe, São Cristóvão, Sergipe, Brazil

${ }^{5}$ Department of Propedeutics, Federal University of Bahia, Salvador, Bahia, Brazil

${ }^{6}$ Department of Chemistry, Federal University of Amazonas, Manaus, Amazonas, Brazil

\section{References}

1 Pontes AF, Barbosa MRV, Maas PJM. Flora Paraibana: Annonaceae Juss. Acta Bot Bras 2004; 18: 281-293

2 Muhammad I, Dunbar DC, Takamatsu S, Walker LA, Clark AM. Antimalarial, cytotoxic, and antifungal alkaloids from Duguetia hadrantha. J Nat Prod 2001; 64: 559-562

3 Matos MF, Leite LI, Brustolim D, de Siqueira JM, Carollo CA, Hellmann AR, Pereira NF, da Silva DB. Antineoplastic activity of selected constituents of Duguetia glabriuscula. Fitoterapia 2006; 77: 227-229

4 Brastianos HC, Sturgeon CM, Roberge M, Andersen RJ. Inhibition of the G2 DNA damage checkpoint by oliveroline isolated from Duguetia odorata. J Nat Prod 2007; 70: 287-288

5 Silva DB, Tulli EC, Militão GC, Costa-Lotufo LV, Pessoa C, de Moraes MO, Albuquerque S, de Siqueira JM. The antitumoral, trypanocidal and antileishmanial activities of extract and alkaloids isolated from Duguetia furfuracea. Phytomedicine 2009; 11: 1059-1063

6 Sousa OV, Del-Vechio-Vieira G, Alves MS, Araújo AA, Pinto MA, Amaral MP, Rodarte MP, Kaplan MA. Chemical composition and biological activities of the essential oils from Duguetia lanceolata St. Hil. Barks. Molecules 2012; 17: 11056-11066

7 Almeida JRGS, Lúcio ASSC, Barbosa-Filho JM, Agra MF, Silva MS, Cunha EVL, Uchoa DEA, Braz-Filho R. Alkaloids and a new cinnamate derivative from Duguetia gardneriana. Biochem System Ecol 2007; 35: 456-458

8 Almeida JRGS, Facanali R, Vieira MAR, Marques MOM, Lúcio ASSC, Lima EO, Agra MF, Barbosa-Filho JM. Composition and antimicrobial activity of the leaf essential oils of Duguetia gardneriana Mart. and Duguetia moricandiana Mart. (Annonaceae). J Essen Oil Res 2010; 22: 275-278

9 Thang TD, Dai DN, Hoi TM, Ogunwande IA. Chemical compositions of the leaf essential oils of some Annonaceae from Vietnam. J Essen Oil Res 2013; 25: 85-91

10 Fechine IM, Navarro VR, Da Cunha EVL, Silva MS, Maia JGS, Barbosa-Filho JM. Alkaloids and volatile constituents from Duguetia flagellaris. Biochem System Ecol 2002; 30: 267-269

11 Siqueira JM, Müller L, Carollo CA, Garcez WS, Boaventura MAD, Nascimiento EA. Aromadendrane sesquiterpenoids from the essential oil of leaves of Duguetia glabriuscula - Annonaceae. J Chil Chem Soc 2003; 48: 89-93 
12 Britto AC, Oliveira AC, Henriques RM, Cardoso GM, Bomfim DS, Carvalho AA, Moraes MO, Pessoa C, Pinheiro ML, Costa EV, Bezerra DP. In vitro and in vivo antitumor effects of the essential oil from the leaves of Guatteria friesiana. Planta Med 2012; 78: 409-414

13 Ribeiro SS, Jesus AM, Anjos CS, Silva TB, Santos AD, Jesus JR, Andrade MS, Sampaio TS, Gomes WF, Alves PB, Carvalho AA, Pessoa C, Moraes MO, Pinheiro ML, Prata AP, Blank AF, Silva-Mann R, Moraes VR, Costa EV, Nogueira $P C$, Bezerra DP. Evaluation of the cytotoxic activity of some Brazilian medicinal plants. Planta Med 2012; 78: 1601-1606

14 Ferraz RP, Cardoso GM, da Silva TB, Fontes JE, Prata AP, Carvalho AA, Moraes MO, Pessoa C, Costa EV, Bezerra DP. Antitumour properties of the leaf essential oil of Xylopia frutescens Aubl. (Annonaceae). Food Chem 2013; 141: 196-200

15 Fontes JEN, Ferraz RP, Britto AC, Carvalho AA, Moraes MO, Pessoa C, Costa $E V$, Bezerra DP. Antitumor effect of the essential oil from leaves of Guatteria pogonopus (Annonaceae). Chem Biodivers 2013; 10: 722-729

16 Quintans JSS, Soares BM, Ferraz RPC, Oliveira ACA, Silva TB, Menezes LRA, Sampaio MFC, Prata APN, Moraes MO, Pessoa C, Antoniolli AR, Costa EV,
Bezerra DP. Chemical constituents and anticancer effects of the essential oil from leaves of Xylopia laevigata. Planta Med 2013; 79: 123-130

17 Ferraz RPC, Bomfim DS, Carvalho NC, Soares MBP, Pinheiro MLB, Costa $E V$, Bezerra DP. Cytotoxic properties of the leaf essential oils of Guatteria blepharophylla and Guatteria hispida (Annonaceae). Flavour Fragr J 2014; 29: 228-232

18 Costa EV, Menezes LRA, Rocha SLA, Baliza IRS, Dias RB, Rocha CAG, Soares $M B P$, Bezerra DP. Antitumor properties of the leaf essential oil of Zornia brasiliensis. Planta Med 2015; 81: 563-567

19 Van Den Dool H, Kratz PD. A generalization of the retention index system including linear temperature programmed gas-liquid partition chromatography. J Chromatogr 1963; 11: 463-471

20 Adams RP. Identification of essential oil components by gas chromatography/mass spectrometry. Carol Stream, IL: Allured Publishing Corporation; 2007

21 Ahmed SA, Gogal RM, Walsh JE. A new rapid and simple non-radioactive assay to monitor and determine the proliferation of lymphocytes an alternative to $[3 \mathrm{H}]$ thymidine incorporation assay. J Immunol Methods 1994; 170: 211-224 